\title{
EFEKTIVITAS PENGGUNAAN MEDIA GAMBAR TIGA DIMENSI TERHADAP HASIL BELAJAR MATEMATIKA PADA SISWA KELAS III
}

\author{
Ernawati \\ Pendidikan Guru Sekolah Dasar, Fakultas Keguruan dan Ilmu Pendidikan, \\ Universitas Muhammadiyah Makassar \\ ernawati@unismh.ac.id
}

\begin{abstract}
Abstrak
Penelitian ini adalah penelitian pre-eksperimental yang melibatkan satu kelas. Tujuan penelitian ini untuk mengetahui hasil belajar dengan menggunakan alagt peraga pada murid kelas III SD Negeri 178 Tanalle Kecamatan Marioriwawo Kabupaten Soppeng. Satuan eksperimen dalam penelitian ini adalah siswa kelas III sebanyak 28 orang. Penelitian dilaksanakan selama 3 kali pertemuan. Hasil penelitian menunjukkan bahwa pembelajaran dengan menggunakan metode konvensional dari 28 murid terdapat 24 orang murid yang berada pada kategori tidak tuntas dengan presentase $85 \%$,dan 4 orang murid yang berada pada kategori tuntas dengan presentase $15 \%$. Secara klasikal belum terpenuhi karena nilai ratarata diperoleh sebesar 38,75 sedangkan pada pembelajaran dengan menggunakan alat peraga terdapat 7 orang murid yang berada pada kategori tidak tuntas dengan presentase $25 \%$, dan 21 orang murid yang berada pada kategori tuntas dengan presentase $75 \%$. Ini berarti ketuntasan belajar memuaskan secara klasikal karena nilai rata-rata 78 telah mencapai KKM yang diharapkan yaitu 70. Berdasarkan hasil penelitian tersebut dapat disimpulkan bahwa dengan menggunakan alat peraga matematika terhadap hasil belajar murid kelas III SD Negeri 178 Tanalle Kecamatan Marioriwawo Kabupaten Soppeng mengalami peningkatan .
\end{abstract}

Kata kunci: Efektivitas, Media Gambar, Tiga dimensi,Hasil Belajar, dan Matematika 


\section{PENDAHULUAN}

Peserta didik secara aktif mengembangkan potensi dirinya untuk memiliki kekuatan, spiritual keagamaan, pengembangan diri, kepribadian, kecerdasan, akhlak mulia serta keterampilan yang diperlukan dirinya, masyarakat, bangsa dan negara.

Pembelajaran di sekolah merupakan wahana pendidikan untuk membina dan membentuk siswa ke arah kedewasaan dan dalam pelaksanaannya berpedoman pada Peraturan Menteri Pendidikan Nasional Nomor 41 Tahun 2007 tentang Standar Proses Satuan Pendidikan pasal 1 ayat 1. Dalam Peraturan Menteri Pendidikan Nasional tersebut dijelaskan bahwa standar pembelajaran satuan pendidikan mencakup perencanaan, pelaksanaan, penilaian, dan pengawasan pembelajaran. Sedangkan dalam Peraturan Menteri Pendidikan Nasional Nomor 22 Tahun 2006 tentang Standar Isi Satuan Pendidikan pasal 1 ayat 1 disebutkan bahwa salah satu di antara mata pelajaran pokok yang diajarkan kepada siswa adalah mata pelajaran matematika.

Matematika diajarkan kepada siswa agar mereka memiliki pola pikir yang sistematis dan rasional seiring dengan peningkatan mutu pendidikan. Hal ini mengacu pada Peraturan Menteri Pendidikan Nasional Nomor 23 Tahun 2006 tentang Standar Kompetensi Lulusan pasal 1 ayat 1 yang menjelaskan bahwa salah satu Standar Kompetensi Lulusan Satuan Pendidikan adalah menunjukkan kemampuan berpikir logis, kritis, kreatif, dan inovatif dalam pengambilan keputusan serta mampu menganalisis serta memecahkan masalah.

Menurut Soedjadi (2000:13) karakterisitik matematika meliputi objek abstrak, kesepakatan deduktif, simbol kosong dari arti, semesta dan konsistensi. Dalam matematika objek dasar yang dipelajari adalah abstrak, objek-objek itu merupakan objek pikiran meliputi fakta, konsep, operasi ataupun relasi, dan prinsip. Dalam pengertian abstrak, biasanya siswa mengalami kesulitan dalam memahami isi materi yang disampaikan oleh guru. Dengan kata lain belajar matematika adalah mempelajari objek kajian yang abstrak, sehingga diperlukan metode dalam menyampaikan materi yang abstrak tersebut agar menjadi konkret, selanjutnya permasalahan tersebut baru dialihkan kebentuk konsep matematika. Pengajaran matematika di sekolah dasar sebagai bagian dari sistem pendidikan nasional, menurut kurikulum 2006, bertujuan antara lain agar siswa memahami konsep matematika, menjelaskan keterkaitan antara konsep pengaplikasian konsep atau algoritma secara luwes dan akurat efesien dan tepat dalam pemecahan masalah.

Pada kenyataannya pembelajaran matematika di sekolah seringkali membuat siswa merasa kesulitan dan bahkan banyak siswa tidak menyukai 
pelajaran matematika. Salah satu materi dalam mata pelajaran matematika yang menuntut siswa untuk dapat berpikir abstrak adalah bangun ruang. Di dalam materi bangun ruang, siswa dituntut untuk bisa membayangkan bagaimana bentuk serta unsur-unsur dari bangun berdimensi tiga ini hanya melalui gambar di dalam buku ataupun di papan tulis yang telah di jelaskan oleh guru mereka. Sehingga tidaklah mengherankan apabila banyak siswa yang mengaku kesulitan dalam memahami materi bangun ruang ini.

Berdasarkan Observasi awal yang di lakukan di SD Negeri 178 Tanalle Kecematan Marioriwawo Kabupaten Soppeng, pembelajaran matematika selama ini masih menggunakan model pembelajaran yang bersifat konvensional, yaitu belum menggunakan media sebagai alat untuk menyampaikan materi pembelajaran agar dapat lebih mengerti oleh siswa. Hal ini mengakibatkan hasil belajar matematika siswa kelas III tergolong dalam kategori rendah. Data persentase hasil belajar matematika siswa kelas III SD Negeri 178 Tanalle di peroleh data yang menunjukkan bahwa lebih dari $60 \%$ siswa belum mencapai nilai KKM, sedangkan nilai KKM yang diterapkan adalah 70 sehingga dapat dikatakan bahwa belum mencapai ketuntasan dalam belajar. Hal ini terjadi karena pada saat pembelajaran berlangsung, masih banyak siswa yang kurang antusias dan tidak menyimak materi yang disampaikan guru, sehingga banyaknya siswa yang tidak dapat menangkap konsep matematika yang mereka pelajari.

Objek matematika adalah benda pikiran yang sifatnya abstrak dan tidak dapat diamati oleh panca indera. Karena itu wajar apabila mata pelajaran matematika tidak mudah dipahami oleh kebanyakan siswa sekolah dasar. Untuk mengatasi hal tersebut, maka dalam mempelajari suatu konsep prinsip-prinsip matematika diperlukan pengalaman melalui benda-benda nyata (konkret), yaitu media tiga dimensi yang dapat digunakan sebagai jembatan bagi siswa untuk berfikir abstrak.

Berdasarkan uraian di atas, penulis berinisiatif untuk mempermudah pemahaman siswa pada mata pelajaran matematika melalui transformasi konsep bangun ruang yang abstrak ke dalam bentuk yang lebih kongkrit (nyata) yaitu dengan menggunakan media pembelajaran tiga dimensi. Media merupakan komponen penting dalam aktivitas pembelajaran. Jika digunakan dengan semestinya komponen ini dapat menentukan kualitas penyampaian informasi dan pengetahuan kepada siswa. Karena alasan itulah penulis perlu melaksanakan penelitian dengan judul "Efektivitas Penggunaan Media Gambar Tiga Dimensi Terhadap Hasil Belajar Matematika Pada Siswa Kelas III SD Negeri 178 Tanalle".

\section{METODE}

Jenis penelitian yang digunakan dalam penelitian ini adalah jenis penelitian eksperimen semu (quasi ekspriment) dengan desain one group 
pretest-posttest design. Adapun prosedur penelitian adalah (a) Tahap Perencanaan, perencanaanya itu tahap permulaan suatu kegiatan sebelum peneliti mengadakan penelitian langsung kelapangan untuk mengumpulkan data, misalnya membuat proposal skripsi, mengurus surat izin untuk mengadakan penelitian kepada pihak-pihak terkait, (b) Tahap Pelaksanaan, Hal yang dilakukan dalam hal ini yakni melakukan penelitian di lapangan guna memperoleh data konkrit dengan menggunakan instrument penelitian yaitu pemberian skala pada siswa dan wawancara pada guru yang bersangkutan, (c) Tahap pengolahan Data. Pada tahap ini, hal yang dilakukan adalah melakukan pengolahan data terhadap data yang diperoleh dari hasil penelitian di sekolah dengan menggunakan perhitungan statistic deskriptif dan statistic inferensial, dan (d) Tahap Pelaporan. Pada tahap ini peneliti menyusun laporan penelitian yang dilakukan dalam bentuk finalisasi penelitian dengan menuangkan hasil pengolahan, analisis, dan kesimpulan tersebut kedalam bentuk tulisan yang disusun secara konsisten, sistematis dan metodologis. Istrument penelitian yang digunakan adalah Observasi dan tes hasil belajar. Teknik Analisis Data yang digunakan untuk menguji hipotesis penelitian yakni analisis statistik deskriptif dan analisi statistik inferensial.

\section{HASIL DAN PEMBAHASAN}

Media tiga dimensi menurut Moedjiono (2002) bahwa media tiga dimensi memiliki beberapa kelebihan diantaranya dapat menunjukkan objek secara utuh baik konstruksi maupun cara kerja, dapat memberikan pengalaman secara langsung, penyajiannya secara konkrit dan menghindari verbalisme. Menurut Rayanda Asyhar (2012) media tiga dimensi memiliki arti sebuah media yang tampilannya dapat diamati dari arah pandang mana saja dan mempunyai dimensi panjang, lebar dan tinggi/tebal, kebanyakan merupakan objek sesungguhnya (real object).

Hal itupun yang saya temukan di lapangan tempat penelitian di SD Negeri 178 Tanalle Kecamatan Marioriwawo Kabupaten Soppeng bahwa penggunaan media gambar tiga dimensi memang sangat efektif digunakan dalam proses pembelajaran khususnya pada materi bangun ruang. Terlihat dari hasil belajar siswa sebelum dilakukan pembelajaran dengan menggunakan hasil belajar hanya 6 orang siswa dari 28 orang siswa yang mencapai ketuntasan hasil belajar, dan setelah pemberian alat peraga dalam proses pembelajaran yang dilaksanakan ketuntasan hasil belajar siswa meningkat yaitu 21 orang siswa yang tuntas dan hanya 7 orang siswa yang tidak tuntas. Ini berarti penggunaan media gambar tiga dimensi memiliki pengaruh nyata dan positif yang diperoleh siswa yang belajar menggunakan 
media gambar tiga dimensi terhadap hasil belajar siswa sesuai dengan teori yang dikemukakan oleh para ahli.

Faktor yang mempengaruhi penggunaan media gambar tiga dimensi sehingga berhasil digunakan dalam pembelajaran matematika di SD Negeri 178 Tanalle Kecamatan Marioriwawo Kabupaten Soppeng yaitu praktis dalam penggunaannya, dapat dipergunakan dihampir semua satuan tingkat pendidikan, dan mudah untuk dibawa sehingga siswa yang sebelumnya kurang memperhatikan pembelajaran karena guru kurang mempertimbangkan pemakaian metode dan alat peraga yang efektif dan sesuai dengan tujuan pembelajaran yang hanya diajar dengan metode ceramah, akhirnya merasa tertarik untuk mengikuti dan memperhatikan pelajaran dan penjelasan guru, sehingga hasil belajar matematika dapat meningkat.

Hasil belajar murid pada mata pelajaran matematika dapat dilihat dari hasil pre-test sebelum diberi perlakuan berada pada kategori sangat rendah, nilai rata-rata hasil belajar murid yaitu 38,75\% dan sangat rendah 36\%, rendah 25\%, sedang 25\%, tinggi $10 \%$ dan sangat tinggi berada pada presentase $4 \%$. Kemudian setelah diberi perlakuan dengan menggunakan alat peraga terjadi peningkatan yang signifikan yaitu berada pada kategori sangat tinggi terlihat dari nilai rata-rata hasil post-test adalah 78\%. Jadi hasil belajar setelah dilaksanakannya lebih baik dengan sebelum dilaksanakannya penggunaan alat peraga. Selain itu persentasi kategori hasil belajar siswa juga meningkat yakni sangat tinggi yaitu 53\% tinggi $21 \%$, sedang $18 \%$, rendah $4 \%$, dan sangat rendah berada pada presentase $4 \%$.

Berdasarkan hasil analisis statistik inferensial dengan menggunakan rumus uji chi kuadrat, dapat diketahui bahwa hasil belajar pre-test dapat

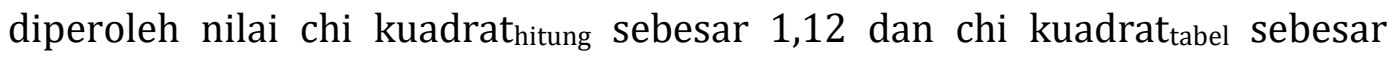
11,07. Sedangkan perhitungan hasil belajar post-test diperoleh nilai chi kuadrat $_{\text {hitung }}$ sebesar 15, 84 dan chi kuadrat tabel $_{11,07}$ hasil pengujian bahwa nilai chi kuadrathitung ternyata memenuhi ktireria, chi kuadrat hitung $\leq$ chi kuadrat $_{\text {tabel }}$ maka dapat disimpulkan bahwa data tersebut berdistribusi normal.

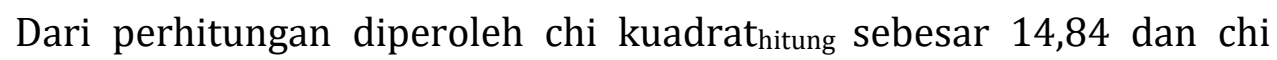
kuadrat $_{\text {tabel }}$ sebesar 11,07 dengan taraf signifikan 0,05. Hasil pengujian bahwa chi kuadrat ${ }_{\text {hitung }}$ ternyata memenuhi kriteria pengujian, chi kuadrat $t_{\text {hitung }} \leq$ dari chi kuadrattabel. Dengan demikian hipotesis alternatif $\left(\mathrm{H}_{1}\right)$ diterima dan hipotesis $\left(\mathrm{H}_{0}\right)$ ditolak.

\section{PENUTUP}

Berdasar hasil penelitian dan pembahasan di kelas III SD Negeri 178 Tanalle Kecamatan Marioriwawo Kabupaten Soppeng, dapat dilihat pada 
kegiatan pre-test hasil belajar matematika siswa kelas IIIyang memperoleh nilai tergolong tinggi dengan presentase 15\% ini berarti ketuntasan belajar tidak memuaskan secara klasikal, karena nilai rata-rata 38,75 tidak mencapai KKM yang diharapkan. Sedangkan pada kegiatan post-test hasil belajar matematika siswa kelas III yang memperoleh nilai tertinggi tergolong tinggi dengan presentase 53\%, dlihat dari ketuntasan belajar memuaskan secara klasikal karena nilai rata-rata siswa meningkat menjadi 78 dan nilai tersebut mencapai KKM yang ditetapkan di sekolah yaitu 70 .

\section{UCAPAN TERIMA KASIH}

Ucapan terima kasih disampaikan kepada SDN 178 Tanalle atas kerjasamanya melakukan penelitian selama 7 Juli sampai 9 September 2017. Dan terima kasih kepada semua pihak yang telah membantu selama penelitian ini dilakukan

\section{DAFTAR PUSTAKA}

Arikunto, Suharsimi. 1998. Prosedur Penelitian Suatu Pendekatan Praktis. Jakarta; PT. Rineka Cipta

Arsyad, 2011.Media Pembelajaran, Jakarta; Rajawali Pers

Asyar,Rayandar. 2012.Kreatif Mengenbangkan Media Pembelajaran.Jakarta; Gaung Pers

Aunurrahman, 2009. Belajar dan Pembelajaran. Bandung: Alfabeta Bundu, Patta. 2012. Asesmen Pembelajaran. Padang; Hayfa Press Djamarah, 2010. Strategi Belajar Mengajar.Jakarta; Rineka Cipta. kini menuju harapan masa depan. Direktorat Jenderal Pendidikan Tinggi Departemen Pendidikan Nasional 1999/2000.

Febri,Yoyok.2012, “Penggunaan Media Tiga Dimensi Dalam Peningkatan Hasil Belajar Matematika Siswa KelasIV Materi Bangun Ruang”,vol 1 ,dalam"file:///C:/Users/ASUS/AppData/Local/Temp/232-604-1-PB1.pdf, diunduh pada 28 agustus 2017

Margono, S. 2010. Metodologi Penelitian Pendidikan. Jakarta; Rineka Cipta Moedjiono, 2012.belajar dan pembelajaran.Jakarta; Rineka Cipta. Peraturan Menteri Pendidikan Nasional No. 22 Tahun 2006 tentang Standar isi Peraturan Menteri Pendidikan Nasional No. 41Tahun 2007 tentang Standar Isi 
Sadiman, 2011.Media Pendidikan Pengertian,Pengembangan, dan Pemanfaatannya. Jakarta; PT Graha Grafindo Persada

Soedjaji, 2000.Kiat Pendidikan Matematika di Indonesia Konstansi keadaan masa

Sudjana, Nana. 2001. Dasar-Dasar Proses Belajar Mengajar. Bandung: Sinar Baru Algensindo

Sugiyono, 2012.Metode Penelitian Pendidikan. Bandung; Alfabeta.

Undang-Undang Republik Indonesia Nomor 20 Tahun 2003 tentang Sistem Pendidikan Nasional. Jakarta: Cemerlang 